Synthesis and characterization of high molecular weight amphoteric terpolymer based on acrylamide, 2-acrylamido-2-methyl-1propanesulfonic acid sodium salt and (3-acrylamidopropyl) trimethylammonium chloride for oil recovery

I. Gussenov ${ }^{1 *}$, N. Mukhametgazy ${ }^{1,2}$ A. Shakhvorostov ${ }^{1}$, S. Kudaibergenov

${ }^{1}$ Institute of Polymer Materials and Technology, Almaty, Kazakhstan ${ }^{2}$ Satbayev University, Almaty, Kazakhstan *E-mail: iskander.gussenov@gmail.com

Акриламид,

2-акриламидо-2-метил-1пропансульфон қышқылды натрий тұзы және

(3-акриламидопропил) триметиламмоний хлориді негізіндегі жоғары молекулалық амфотерлі терполимердің синтезі мен сипаттамасы

И. Гусенов ${ }^{1 *}$, Н. Мұхаметғазы ${ }^{1,2}$ А. Шахворостов ${ }^{1}$, С. Құдайбергенов

${ }^{1}$ Полимерлік материалдар және технологиялар институть Алматы, Қазақстан

2Satbayev University, Алматы, Қазақстан *E-mail: iskander.gussenov@gmail.com
High molecular weight amphoteric terpolymer based on a nonionic monomer, acrylamide (AAm), an anionic monomer, 2-acrylamido-2-methyl-1-propanesulfonic acid sodium salt (AMPS), and a cationic monomer, (3-acrylamidopropyl) trimethylammonium chloride (APTAC), was prepared using free-radical copolymerization in an aqueous solution and characterized by ${ }^{1} \mathrm{H}$ NMR, FTIR, GPC, DLS, zeta potential and viscometry. The polymer was shown to be viscosifying, and therefore can be utilized as a polymer flooding agent in the high salinity and temperature conditions of oil reservoirs. Injection of $0.25 \mathrm{wt} . \%$ of amphoteric terpolymer, dissolved in 200-300 g. $\mathrm{L}^{-1}$ brine, into high and low permeability sand pack models demonstrated that the oil recovery factor (ORF) increases by up to $23-28 \%$ in comparison with saline water flooding. This is explained by an increase in the viscosity of brine solution due to disruption of intra- and interionic contacts between oppositely charged AMPS and APTAC moieties, demonstrating the antipolyelectrolyte effect. In high saline water, the anions and cations of salts screen the electrostatic attraction between positively and negatively charged macroions, resulting in expansion of the macromolecule. This phenomenon leads to an increase in the viscosifying effect on the brine solution, thus decreasing the mobility factor (M), which is defined as the ratio of displacing phase mobility (water) to displaced phase mobility (oil).

Keywords: amphoteric terpolymer; synthesis; characterization; core flooding; filtration; oil displacement.

Молекулалық салмағы жоғары амфотерлі терполимер бейтарап - акриламид (ААм), аниондық мономер - 2-акриламидо-2-метил-1-пропансульфон қышқылды натрий тұзы (АМПСК), катионды мономер - (3-акриламидопропил) триметиламмоний хлорид (АПTMAX) негізінде бос радикалды сополимерлену әдісімен синтезделді және ${ }^{1} \mathrm{H}$ ЯМР, ИК Фурье спектроскопия, гель-өткізгіштік хроматография, жарықтың динамикалық шашырауы, дзета потенциалы және тұтқырлығы арқылы сипатталады. Ол қоюлатқыш және полимерл айдау агенті ретінде жоғары тұздылықта және температуралық жағдайында сыналды. 200$300 г^{-1}$ тұзды ерітіндісінде еріген амфотерлі терполимердің 0,25\% жоғары және төмен өткізгіштігі бар құм үлгісіне айдау мұнайдың өндіру коэффициентінің (МӨК) тұзды сумен айдауға салыстырғанда 23-28\% өсетіндігін көрсетті. Бұл антиэлектролиттік әсер көрсете отырып, қарама-қарсы зарядталған AMPS және APTAC мономерлер арасындағы ішкі- және аралық байланыстардың бұзылуынан, сонымен қатар тұзды ерітінді тұтқырлығының жоғарылауымен түсіндіріледі. Жоғары тұзды сүда тұзды аниондар мен катиондар оң және теріс зарядталған макроиондар арасындағы электростатикалық тартылысты экранға шығарады, ал макромолекулалық тізбек ашылады. Бұл ерітіндінің тұтқырлығының жоғарылауына, демек қоюлану әсеріне әкеледі. Өз кезегінде, тұзды ерітіндінің қоюлануь қозғалғыштық коэффициентінің төмендеуіне әкеледі (М), бұл ығысу фазасының (судың) қозғалғыштығының ығысқан фазаның (майдың) қозғалғыштығына қатынасы ретінде анықталады.

Түйін сөздер: амфотерлі терполимер; синте; сипаттама; кернді суландыру; фильтрлеу; мұнайды ығыстыру.
Синтез и изучение высокомолекулярного амфотерного терполимера на основе акриламида, натриевой соли

2-акриламидо-2-метил1-пропансульфоновой кислоты и

(3-акриламидопропил) триметиламмоний хлорида для вытеснения нефти

И. Гусенов ${ }^{1 *}$ Н. Мухаметгазы ${ }^{1,2}$ А. Шахворостов ${ }^{1}$, С. Кудайбергенов

${ }^{1}$ Институт полимерных материалов и технологий, Алматы, Казахстан ${ }^{2}$ Satbayev University, Алматы, Казахстан *E-mail: iskander.gussenov@gmail.com
Высокомолекулярный амфотерный терполимер, состоящий из неионогенного мономера - акриламида (ААм), анионного мономера - натриевой соли 2-акриламидо2-метил-1-пропансульфоновой кислоты (АМПС), катионного мономера - (3-акриламидопропил) триметиламмоний хлорида (АПТАХ) был синтезирован методом свободнорадикальной сополимеризации и охарактеризован методами ${ }^{1} \mathrm{H}$ ЯМР, ИК Фурье спектроскопии, гель-проникающей хроматографии, динамического лазерного светорассеяния, дзета-потенциала и вискозиметрии. Терполимер был испытан в качестве агента для полимерного заводнения в условиях высокой минерализации воды и температүры. Закачка 0,25\% раствора амфотерного терполимера в воде с минерализацией 200-300 г $л^{-1}$ в высоко- и низкопроницаемые песчаные модели показала, что коэффициент вытеснения нефти (КВН) увеличивается на 23-28\% по сравнению с обычным заводнением. Это объясняется увеличением вязкости раствора вследствие разрушения внутри- $и$ межионных контактов между противоположно заряженными АМПС И АПТАХ, что демонстрирует антиполиэлектролитный эффект. В высокоминерализованной пластовой воде анионы и катионы солей экранируют электростатическое притяжение между положительно и отрицательно заряженными макроионами и макромолекулярная цепь разворачивается. Это приводит к увеличению вязкости раствора и, следовательно, $к$ загущающему эффекту. В свою очередь, увеличение вязкости воды приводит к уменьшению коэффициента подвижности (М), который определяется как отношение подвижности вытесняющей фазы (воды) к подвижности вытесняемой фазы (нефти).

Ключевые слова: амфотерный терполимер; синтез; характеристики; заводнение керна; фильтрация; вытеснение нефти. 


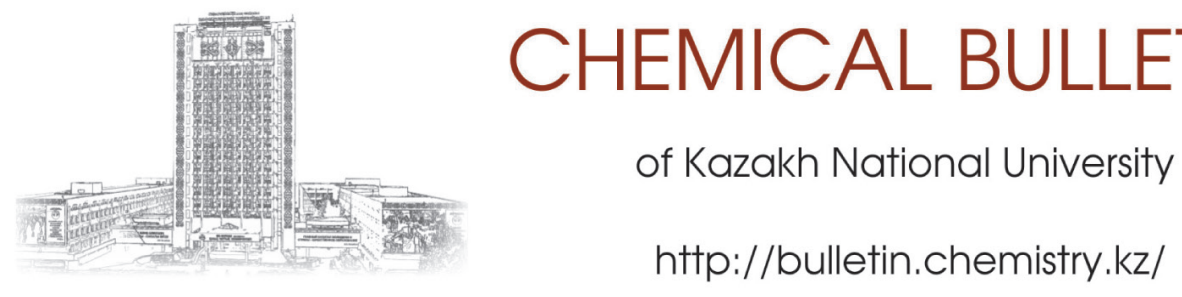

\title{
Synthesis and characterization of high molecular weight amphoteric terpolymer based on acrylamide, 2-acrylamido-2-methyl-1-propanesulfonic acid sodium salt and (3-acrylamidopropyl)trimethylammonium chloride for oil recovery
}

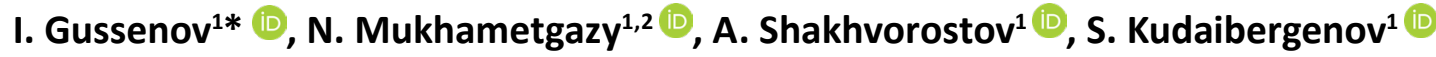 \\ ${ }^{1}$ Institute of Polymer Materials and Technology, 3/1 microdistrict "Atyrau 1", 050019 Almaty, Kazakhstan \\ ${ }^{2}$ Satbayev University, 22a Satbayev str., 050013 Almaty, Kazakhstan \\ *E-mail: isakander.gusenov@mail.ru
}

\section{Introduction}

Primarily, water is used to displace oil from matrix rocks. However, because of an unstable displacement front due to the differences in oil and water viscosities and the heterogeneous nature of matrix rocks, oil production rates often decline along with an increase in water cut [1]. In order to prevent water from bypassing oil, the following actions are required: 1) water permeability reduction; 2) oil viscosity reduction; 3) oil permeability increase; and, 4) water viscosity increase. Based on this concept, the mobility factor $(M)$ was introduced in order to quantitatively assess oil displacement by water [2]:

$$
M=\frac{k_{w} \cdot \mu_{o}}{k_{o} \cdot \mu_{w}}
$$

where $M$ - mobility factor; $k_{w}$ - water permeability; $\mu_{o}-$ oil viscosity; $k_{o}$ - oil permeability; $\mu_{w}$ - water viscosity.

Whereas, the first three above listed tasks are challenging in practice, the fourth task of increasing water viscosity can be achieved by using high molecular weight polymers [2]. The increase in the viscosity of the injected water as an oil displacing agent after the addition of high molecular weight polymers results in substantial acceleration of oil production [3]. This is explained by a reduction in the propagation velocity of water in matrix rocks in relation to that of the oil, and as a result the injected water sweeps more oil. Indeed, polymer flooding has been shown to be an effective method of unlocking viscous oil resources [4].

Hydrolyzed polyacrylamide (HPAM) is widely used to increase water viscosity. The expansion of the polymer molecule, due to the repulsion between negatively charged groups on HPAM chains, results in an increase in the viscosity of the solution. However, if cations are present in water, the negative charges on the polymer chain are screened, so the hydrodynamic volume of the polymer molecule is reduced [57]. At higher salinities, greater concentrations of HPAM are therefore required in order to achieve the target viscosity. At extremely high salinity and temperature, HPAM chains coil up and precipitate [8].

The ability of amphoteric polyelectrolytes to swell and be effective viscosity enhancers in reservoirs with high salinity and temperatures plays a crucial role in the enhanced oil recovery (EOR) processes $[9,10]$. Due to their salt- and temperature resistance, strongly charged, or quenched, polyampholytes can serve as viscosifying agents in EOR when thickeners are required in brine solution [11,12]. In this regard, amphoteric polyelectrolytes, being polymers that have both cationic and anionic groups, are promising, because in high salinity water, the anions and cations screen the electrostatic attraction between the positively and negatively charged groups of the polymer chain, thus the chain expands, increasing the viscosity of the solution [9-11].

Previously [12], the current project team studied the applicability of amphoteric terpolymers [AAm]:[AMPS]:[APTAC] $=50: 25: 25 ; 60: 20: 20 ; 70: 15: 15 ; 80: 10: 10$ and $90: 5: 5$ mol. $\%$ for oil 
recovery, and found that only the sample of $80: 10: 10 \mathrm{~mol} . \%$ increased oil recovery by up to $4.8-5 \%$ under oil reservoir conditions (salinity of $163 \mathrm{~g} \cdot \mathrm{L}^{-1}$ and temperature of $60^{\circ} \mathrm{C}$ ). The low value of oil recovery by AAm-AMPS-APTAC terpolymers was assessed as being connected to the low molecular weight of the synthesized terpolymers.

In the present research, the team synthesized a high molecular weight amphoteric terpolymer of AAm-AMPS-APTAC $=80: 10: 10 \mathrm{~mol} . \%$, characterized it using various physicochemical methods, and studied its oil recovery effectiveness in sand pack models of different permeability and under conditions of extremely high salinity and at a fixed temperature.

\section{Experiment}

\subsection{Materials}

\subsubsection{Monomers}

The monomers included: acrylamide (AAm, 97\% purity), 2-acrylamido-2-methylpropanesulfonic acid sodium salt (AMPS, 50 wt.\%), (3-acrylamidopropyl) trimethylammonium chloride (APTAC, 75 wt.\% in water), and ammonium persulfate (APS, 98\% purity). All were purchased from Sigma-Aldrich Chemical Co., and used without further purification.

\subsubsection{Sand pack model}

To simulate oil displacement by water and polymers, high permeability $3-\mathrm{cm}$-diameter and 5 -cm-length sand packs were used. The size of the sand grains varied between 0.25 and $0.5 \mathrm{~mm}$. Two sand packs were used in these experiments (Table 1).

Table 1 - Properties of the sand packs

\begin{tabular}{cccc}
\hline $\begin{array}{c}\text { Sand } \\
\text { pack }\end{array}$ & $\begin{array}{c}\text { Pore volume, } \\
\mathrm{cm}^{3}\end{array}$ & $\begin{array}{c}\text { Porosity, } \\
\%\end{array}$ & $\begin{array}{c}\text { Permeability, } \\
\text { Darcy }\end{array}$ \\
\hline 1 & 10.6 & 30 & 0.62 \\
2 & 10.95 & 31 & 1.8 \\
\hline
\end{tabular}

\subsubsection{Brine}

Brines with different salinities were used in this study. The salinity and chemical composition of the different brines are listed in Table 2.

Table 2 - Chemical composition of brines

\begin{tabular}{cccc}
\hline \multirow{2}{*}{$\begin{array}{c}\text { Salinity, } \\
\mathrm{g} / \mathrm{L}\end{array}$} & $\mathrm{NaCl}$ & $\mathrm{CaCl}_{2}$ & $\mathrm{MgCl}_{2}$ \\
\hline 200 & 180 & 10 & 10 \\
232 & 208.8 & 11.6 & 11.6 \\
250 & 225 & 12.5 & 12.5 \\
275 & 247.5 & 13.75 & 13.75 \\
300 & 270 & 15 & 15 \\
\hline
\end{tabular}

\subsubsection{Oil}

Crude oil from the Karazhanbas oilfield, well \#1913, was used. Oil viscosity and density at $30^{\circ} \mathrm{C}$ are equal to $420 \mathrm{cp}$ and $0.93 \mathrm{~g} \cdot \mathrm{cm}^{-3}$.

\subsection{Methods}

\subsubsection{Synthesis of AAm-AMPS-APTAC terpolymer}

The amphoteric terpolymer was synthesized via conventional free radical (co)polymerization as previously described by the team [12]. The synthetic protocol of AAmAPTAC-AMPS terpolymer is given in Table 3. The terpolymer obtained was used in the oil displacement experiment without further purification.

Table 3 - Synthetic protocol of AAm-APTAC-AMPS terpolymer

\begin{tabular}{|c|c|c|c|c|c|c|c|}
\hline \multicolumn{3}{|c|}{$\begin{array}{l}\text { Initial feed composition, } \\
\text { mol. \% }\end{array}$} & \multirow{2}{*}{$\begin{array}{l}\text { AAm, } \\
\text { g }\end{array}$} & \multirow{2}{*}{$\begin{array}{c}\text { APTAC, } \\
\text { g }\end{array}$} & \multirow{2}{*}{$\begin{array}{c}\text { AMPS, } \\
\mathrm{g}\end{array}$} & \multirow{2}{*}{$\begin{array}{l}\text { APS, } \\
\mathrm{mg}\end{array}$} & \multirow{2}{*}{$\begin{array}{l}\mathrm{H}_{2} \mathrm{O}, \\
\mathrm{mL}\end{array}$} \\
\hline AAm & APTAC & AMPS & & & & & \\
\hline 80 & 10 & 10 & 2.75 & 1.33 & 2.22 & 11.0 & 3.2 \\
\hline
\end{tabular}

\subsubsection{Characterization of AAm-AMPS-APTAC terpolymer}

FTIR spectra of AAm-AMPS-APTAC terpolymer were recorded on a Cary 660 FTIR (Agilent, USA). ${ }^{1} \mathrm{H}$ NMR spectra in $\mathrm{D}_{2} \mathrm{O}$ were done on an impulse Fourier NMR spectrometer from Avance-III 500MHz (Bruker, Germany). Gel permeable chromatography (GPC) was carried out on a Viscotek GPC/SEC (UK). Dynamic light scattering (DLS) and zeta-potential measurements were completed using a Zetasizer NanoZS 90 (Malvern, UK), equipped with a $633 \mathrm{~nm}$ laser source. Thermogravimetric analyses (TGA) were conducted on a LabSys Evo (Setaram, France), at a temperature range of 30 to $500^{\circ} \mathrm{C}$ and heating rate of $10^{\circ} \mathrm{C} / \mathrm{min}$. The SEM images were obtained on a Crossbeam 540 (Germany) by placing dry polymer powder coated with gold nanoparticles on carbon tape. The TEM images were made on a JEOL JEM 1400 Plus (USA) by placing one drop of $0.01 \mathrm{wt}$.\% polymer solution in $\mathrm{D}_{2} \mathrm{O}$ on a copper cell $(\mathrm{d}=2 \mathrm{~mm})$ and drying the sample overnight in a refrigerator. The dynamic viscosities of the polymer solutions were measured using a capillary Ostwald viscometer with capillary diameters of 0.54 and $1.16 \mathrm{~mm}$, at 24 and $60^{\circ} \mathrm{C}$. The reduced viscosity was measured on a Ubbelohde viscometer at 24 and $60^{\circ} \mathrm{C}$.

\subsubsection{Sand pack flooding}

Sand pack flooding was conducted with the help of a special core flooding set up "УИК-С(2)" (Russia) in the following sequence: 1) vacuuming of the sand pack; 2) saturation with brine; 3) porosity and permeability measurements; 4) brine displacement with oil till irreducible water saturation was reached; 5) water flooding simulation using 1 pore volume of brine injection; and, 6) polymer flooding simulation using 2.5 pore volumes of $0.25 \mathrm{wt} . \%$ polymer solution injection. The confining pressure was set at $2 \mathrm{MPa}$, ambient temperature was equal to $30^{\circ} \mathrm{C}$, and the fluids were injected at $0.15 \mathrm{~cm}^{3} \cdot \mathrm{min}^{-1}$. 
The outlet section of the model was open to atmosphere. The fluids were injected using high pressure piston pumps, the temperature was set by wrapping a heating tape around the model, and PC connected pressure transducers were used to register the inlet pressure values during the tests.

\section{Results and Discussion}

3.1 Synthesis and characterization of AAm-AMPS-APTAC terpolymer

Linear terpolymers of AAm-APTAC-AMPS were synthesized via classical free radical (co)polymerization (Figure 1). The resulting copolymer has a random distribution of charged groups along the macromolecular chain.

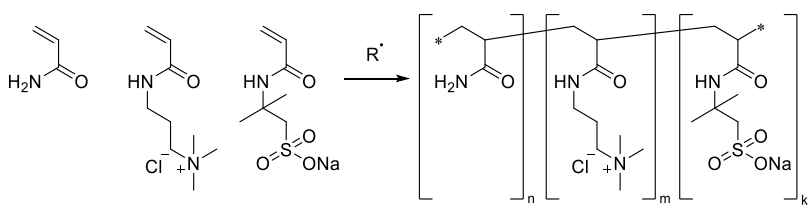

Figure 1 - Synthesis of AAm-APTAC-AMPS terpolymer

An FTIR spectrum of the amphoteric terpolymer is shown in Figure 2. The wide absorption band in the region of 3200$3500 \mathrm{~cm}^{-1}$ corresponds to the $\mathrm{NH}_{2}$ groups of $\mathrm{AAm}$, and the absorption bands in the region of $2800-3000 \mathrm{~cm}^{-1}$ correspond to the asymmetric and symmetric vibrations of the $\mathrm{CH}$ groups. The absorption bands at 1660 and $1546 \mathrm{~cm}^{-1}$ belong to the vibrations of the $\mathrm{N}$-substituted groups, Amide I and Amide II, respectively. The absorption band at $1450 \mathrm{~cm}^{-1}$ is characteristic of the deformation vibrations of the $\mathrm{CH}$ groups. Finally, the absorption band in the region of $1190 \mathrm{~cm}^{-1}$ is related to the symmetrical $\mathrm{S}=\mathrm{O}$ stretching vibration of AMPS.

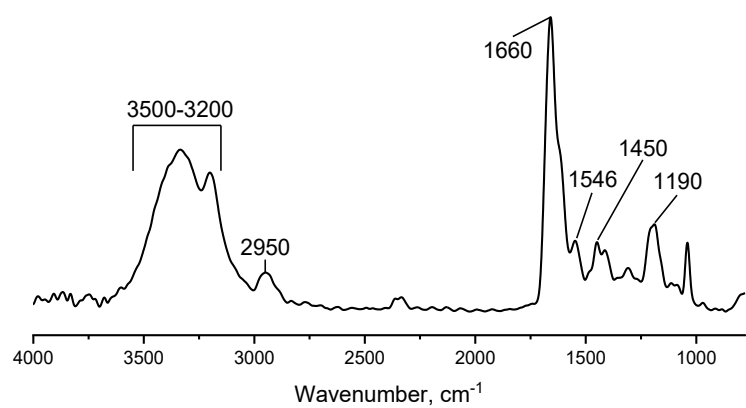

Figure 2 - FTIR spectrum of AAm-APTAC-AMPS terpolymer

The structure of AAm-APTAC-AMPS terpolymer was established using ${ }^{1} \mathrm{H}$ NMR spectroscopy (Figure 3 ). The broad resonance peaks at 1.6-1.8 and $2.3 \mathrm{ppm}$ were attributed to the protons of the methylene and methine groups of the main

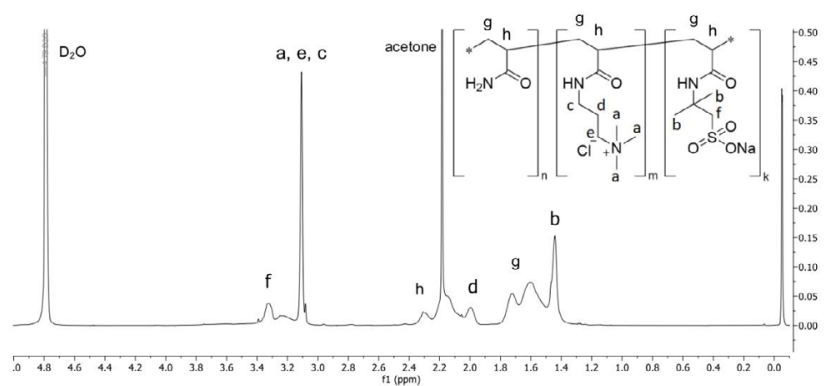

Figure $3-{ }^{1} \mathrm{H}$ NMR spectrum of AAm-APTAC-AMPS terpolymer

polymer chain, respectively. However, these peaks overlap with those of the methyl and methylene protons of AMPS and APTAC. The peaks at $3.1-3.3 \mathrm{ppm}$ were assigned to the suspended protons of the methyl and methylene groups of AMPS and APTAC. Two methylene groups of AMPS are responsible for the appearance of the peak at $1.4 \mathrm{ppm}$.

3.2 Determination of the molecular weights of AAmAPTAC-AMPS terpolymer

Figure 4 and Table 4 represent the GPC data and molecular weights of AAm-APTAC-AMPS terpolymer measured in aqueous solution. The weight-average molecular weight $\left(M_{w}\right)$ and the average-number molecular weight $\left(M_{n}\right)$ of the terpolymer was equal to $2.9 \cdot 10^{6}$ and $2.1 \cdot 10^{6}$ Dalton, respectively. The polydispersity index (PDI) of the terpolymer is quite low for conventional free radical polymerization. The relatively high monomer concentration in the reaction mixture is considered to be responsible for the low PDI. The high molecular weight and low PDI of the terpolymer are expected to be suitable for oil recovery.

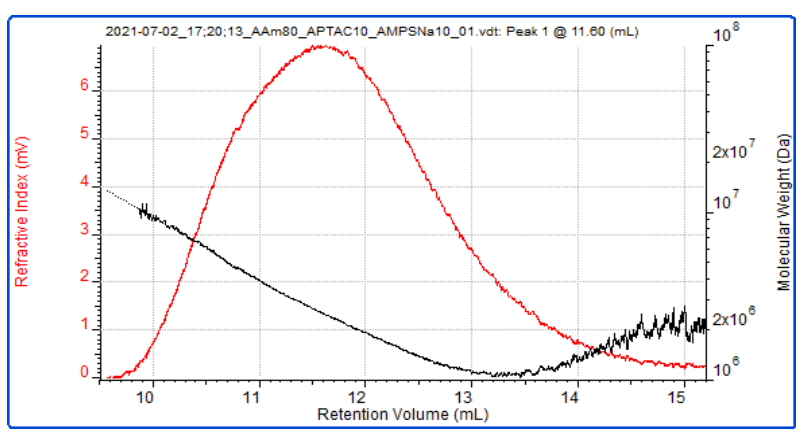

Figure 4-GPC of AAm-APTAC-AMPS terpolymer in aqueous solution

Table 4- $M_{w^{\prime}}, M_{n}$ and PDI of AAm-APTAC-AMPS terpolymer

\begin{tabular}{|c|c|c|c|c|c|}
\hline \multicolumn{3}{|c|}{ Composition, mol. \% } & \multirow{2}{*}{$\begin{array}{l}\mathrm{M}_{\mathrm{w}} \cdot 10^{6} \\
\text { Dalton }\end{array}$} & \multirow{2}{*}{$\begin{array}{l}\mathrm{M}_{\mathrm{n}} \cdot 10^{6} \\
\text { Dalton }\end{array}$} & \multirow{2}{*}{$P D I=M_{w} / M_{n}$} \\
\hline AAm & APTAC & AMPS & & & \\
\hline 80 & 10 & 10 & 2.9 & 2.1 & 1.36 \\
\hline
\end{tabular}




\subsection{TGA analysis of AAm-APTAC-AMPS terpolymers}

Figure 5 shows the TGA thermogram of the amphoteric terpolymer together with the differential curve. The terpolymer exhibits the typical thermal behavior of acrylamide-based polymers [13]. Significant mass loss occurs at 318 and $402^{\circ} \mathrm{C}$. The first mass loss at $318^{\circ} \mathrm{C}$ is probably attributable to the glass transition temperature $\left(T_{g}\right)$, whereas the second mass loss at $402^{\circ} \mathrm{C}$ is indicative of thermal decomposition. The value of $\mathrm{Tg}$ depends on the mobility of the polymer chain and reflects the transition from the glass to the rubber-like state as an important feature of polymer behavior. It is concluded that the thermal stability of the terpolymer is rather high and suitable for application at high temperatures in oil reservoirs.

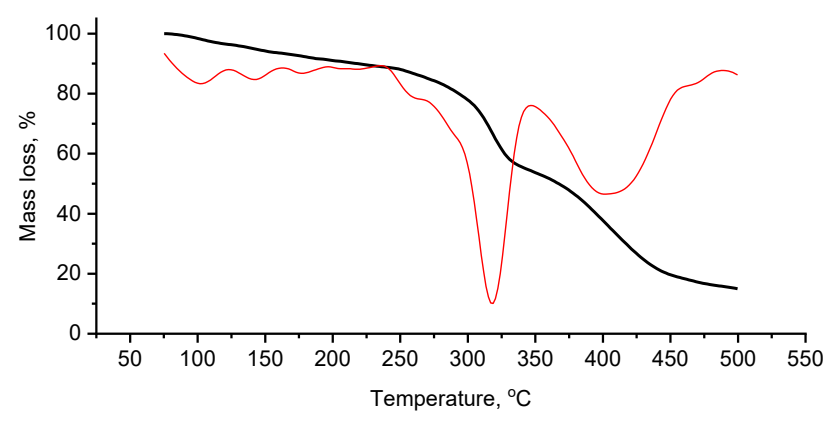

Figure 5 - TGA thermogram of AAm-APTAC-AMPS terpolymer (black line), and its differential curve DTGA (red line). The values of $T_{g}$ and decomposition temperature are indicated by dotted lines.

3.4 DLS measurement of AAm-APTAC-AMPS terpolymer in pure water and brine

The average hydrodynamic size of AAm-APTAC-AMPS terpolymer is shown in Figure 6. In pure water, the terpolymer has a broad size distribution with a maximum at 50-60 nm and a small shoulder at $350-400 \mathrm{~nm}$. In brine solutions, a bimodal size distribution is observed, and two well separated maxima appear at $25-30 \mathrm{~nm}$ and $300-340 \mathrm{~nm}$. It is supposed that in pure water the macromolecular chains are mostly in aggregated state. At high salt solutions $(200-250 \mathrm{~g} / \mathrm{L})$ these aggregates destruct and are fractionated to lower $(25-30 \mathrm{~nm})$ and higher $(300-340 \mathrm{~nm})$ molecular weight fractions. Increasing of the intensity of both low molecular weight and high molecular weight fractions is probably due to unfolding and increasing of hydrodynamic volume of macromolecules. These data are in god agreement with increasing of the dynamic viscosities of AAm-APTAC-AMPS terpolymer measured at 200-250 g/L brine (see Figure 9). The zeta potential of the terpolymer solutions, dissolved in pure water and in a concentration range of 0.25 $0.016 \%$, was negligible negative at -3.4 to $-6.8 \mathrm{mV}$. This negative charge is due to a small excess of AMPSNa in the main polymer chain and is indicative of the different reactivity of the monomers.

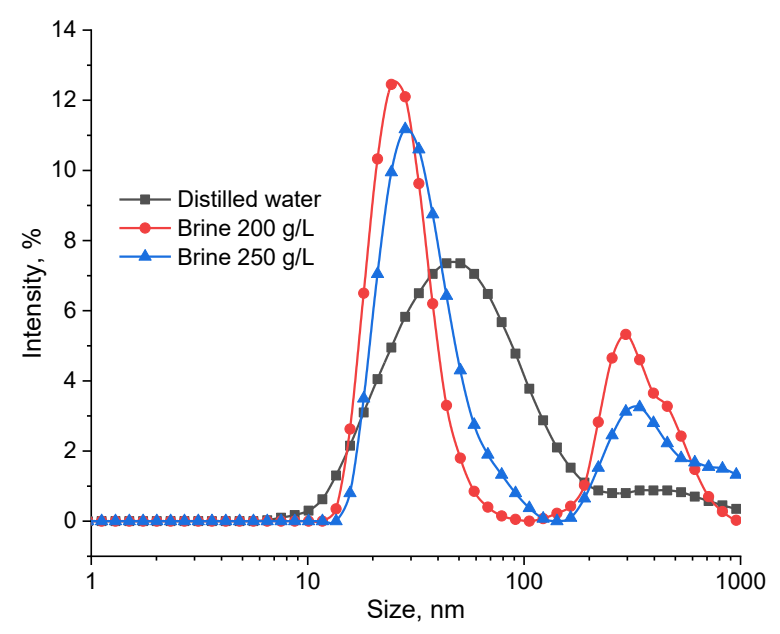

Figure 6 - The effect of brine solution on the average hydrodynamic size of AAm-APTAC-AMPS terpolymer

\subsection{SEM and TEM results}

Figure 7 shows the SEM and TEM images of AAm-APTACAMPS terpolymer in the form of powder and thin film, respectively. The micron-sized SEM image of the terpolymer is specific to the most amorphous polymers, and not very informative. In contrast, the TEM image of the terpolymer exhibits two kinds of spherical nanoparticles, small and large, with average sizes of 25-30 nm and 200-250 nm, respectively. Moreover, the number of small nanoparticles is vastly larger than the quantity of large ones. This result coincides well with the average hydrodynamic size of the terpolymer determined by DLS (see Figure 6). As follows from the DLS data, the number of small nanoparticles with an average size of 50-60 nm is far in excess of the quantity of large nanoparticles with an average size of $350-400 \mathrm{~nm}$. A discrepancy is observed between the particle sizes determined by DLS and TEM. The particle sizes registered by TEM represent the compact polymer particles without hydrated shells. Whereas, DLS results show greater sizes of polymer particles due to the swollen state of the macromolecules in aqueous solution and formation of hydrated shells around the polymer chains.

\subsection{Viscosity data}

The effect of polymer concentration on the dynamic and reduced viscosities of AAm-AMPS-APTAC terpolymer in $250 \mathrm{~g} \cdot \mathrm{L}^{-1}$ synthetic brine is shown in Figure 8 . The intrinsic viscosity [ $\eta]$ of the terpolymer is found by extrapolation of $\eta_{s p} / C$ to $C \rightarrow 0$ to be equal to 20 and $8.3 \mathrm{dL} \cdot \mathrm{g}^{-1}$ at 24 and $60^{\circ} \mathrm{C}$, respectively. The high values of the intrinsic viscosities of the terpolymer in $250 \mathrm{~g} \cdot \mathrm{L}^{-1}$ salt solution confirm the preparation of high molecular weight quenched polyampholyte by radical polymerization.

The gradually decreasing dynamic and reduced viscosities of the terpolymer during dilution confirms the absence of the polyelectrolyte effect, leading to unfolding of macromolecular coils upon dilution. The polyelectrolyte effect is usually specific 
a)

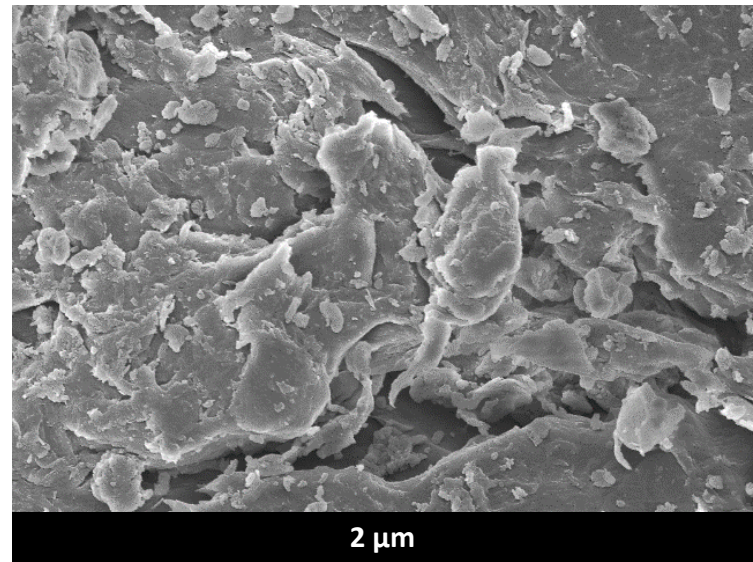

b)

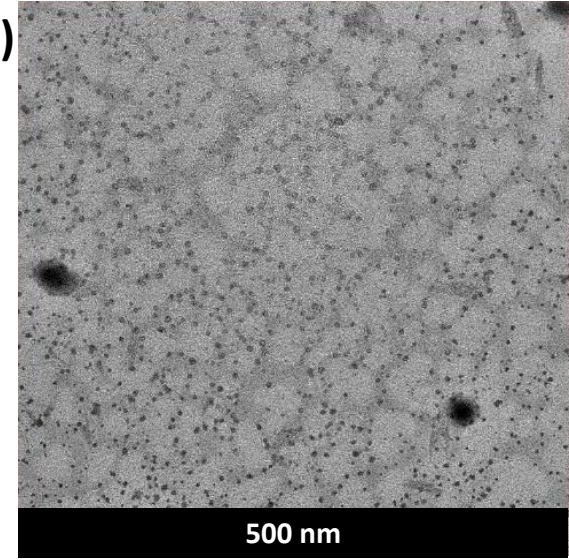

Figure 7 - SEM (a) and TEM (b) images of AAm-APTAC-AMPS terpolymer
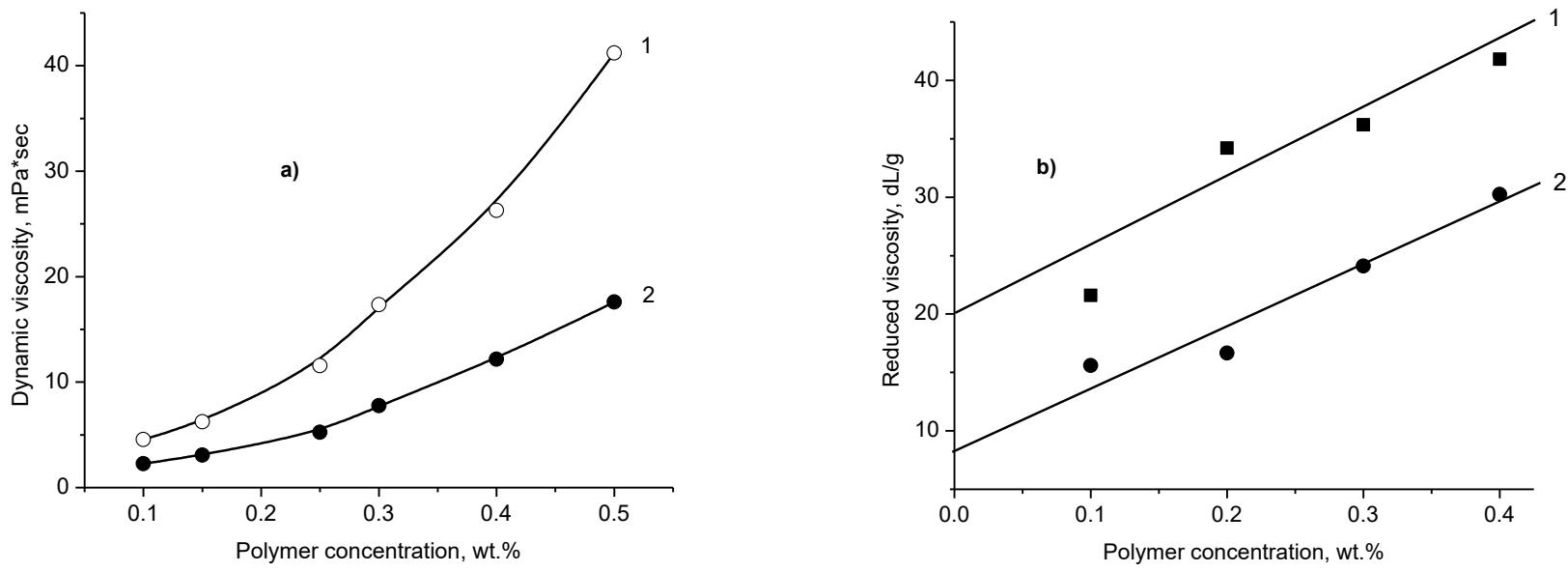

Figure 8 - Dependence of the dynamic (a) and reduced (b) viscosities of amphoteric terpolymer on polymer concentration at $24^{\circ} \mathrm{C}(1)$ and $60^{\circ} \mathrm{C}(2)$ in $250 \mathrm{~g} \cdot \mathrm{L}^{-1}$ synthetic brine

to anionic and cationic polyelectrolytes, due to electrostatic repulsion between uniformly distributed negative or positive charges along the macromolecular chains $[9,10]$. In the case of charge-balanced terpolymer AAm-AMPS-APTAC, the polyelectrolyte effect is fully suppressed due to mutual compensation of oppositely the charged monomers, AMPS and APTAC. The low values of the dynamic and reduced viscosities at a high temperature of $60^{\circ} \mathrm{C}$ are probably accounted for by destruction of intra- and inter-macromolecular hydrogen bonds between acrylamide monomers, and by enhancement of hydrophobic interactions between the backbones of the main polymer chain.

The dynamic viscosity of the 0.25 wt.\% terpolymer solution was found to increase with a rise in brine salinity from 200 to $300 \mathrm{~g} \cdot \mathrm{L}^{-1}$ at 24 and $60^{\circ} \mathrm{C}$ (Figure 9).

The increase of dynamic viscosity with an increase in brine salinity is explained by the screening of the electrostatic attraction between positively and negatively charged

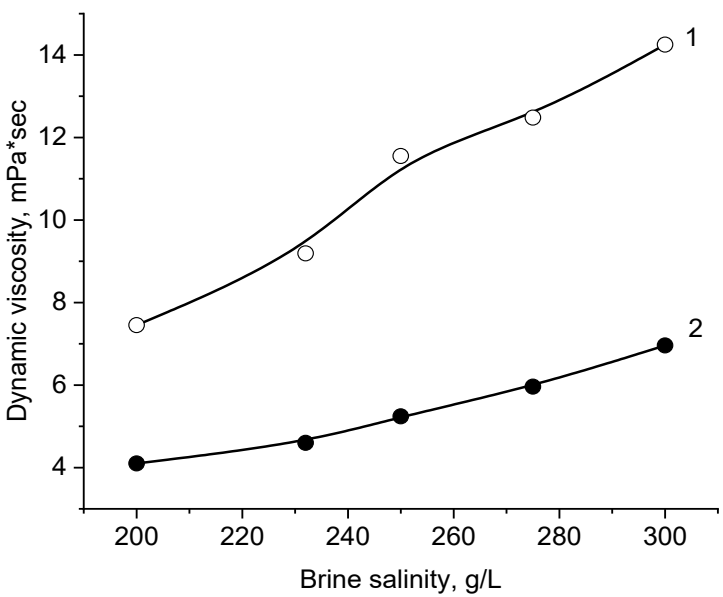

Figure 9 - Salt-dependent dynamic viscosity of the amphoteric terpolymer at $24(1), 60^{\circ} \mathrm{C}$ (2) 


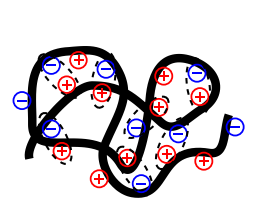

Charge-balanced quenched polyampholyte

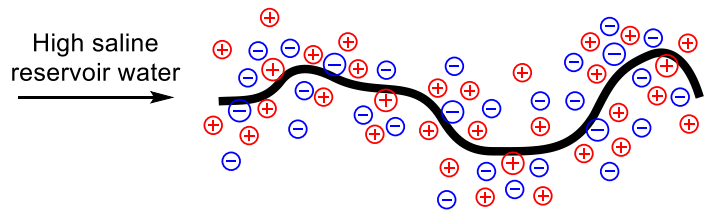

$\oplus$ Cationic monomer

$\Theta$ Anionic monomer

: $\Phi$ ) lonic or salt bridge

$\Theta$ Salt anion

$\oplus$ Salt cation

Figure 10 - Schematic illustration of the behavior of AAmAMPS-APTAC terpolymer in high saline water. Black thick line represents polymer backbone.

monomers by anions and cations of salts, which leads to expansion of the polymer chain. This phenomenon is called the antipolyelectrolyte effect, which is illustrated in Figure 10. Increasing the dynamic viscosity of the high molecular weight terpolymer in brine is favorable for viscosification of hot reservoir water containing up to $200-300 \mathrm{~g} \cdot \mathrm{L}^{-1}$ salts.

\subsection{Sand pack flooding}

Figure 11 shows changing of injection pressure versus time in the course of the oil saturation process for the $0.62 \mathrm{D}$ and $1.8 \mathrm{D}$ sand pack models.

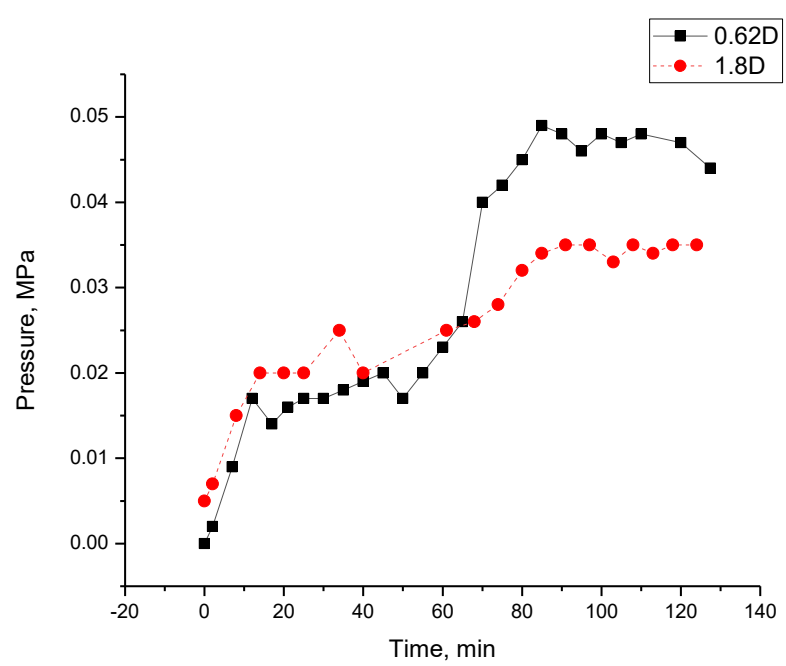

Figure $\mathbf{1 1}$ - Injection pressure versus time in the course of the oil saturation process

At a high oil injection pressure of $0.044-0.047 \mathrm{MPa}$, stabilization occurs in the lower permeability model, as seen in Figure 11 . For the higher permeability model $(1.8 \mathrm{D})$, the oil injection pressure leveled off at $0.035 \mathrm{MPa}$. The mass of oil in each model was calculated based on material balance, and was found to be equal to $8.78 \mathrm{~g}$ and $9.47 \mathrm{~g}$ for the $0.62 \mathrm{D}$ and $1.8 \mathrm{D}$ models, respectively.

\subsection{Water and polymer flooding}

Figure 12 shows the mass of produced oil versus pore volumes injected into the sand packs during the water flooding. In spite of large permeability differences, the oil production curves are not substantially different. However, the injection pressure is notably higher in the case of the lower permeability sand pack (Figure 13). Figure 13 shows that immediately following the start of polymer injection, oil production increases up to $0.35 \mathrm{~g}$, then reaches a limit as indicated by a decline in the oil flow rate. The injection pressure is slightly increased in the case of the low permeability sand pack (1.8D).

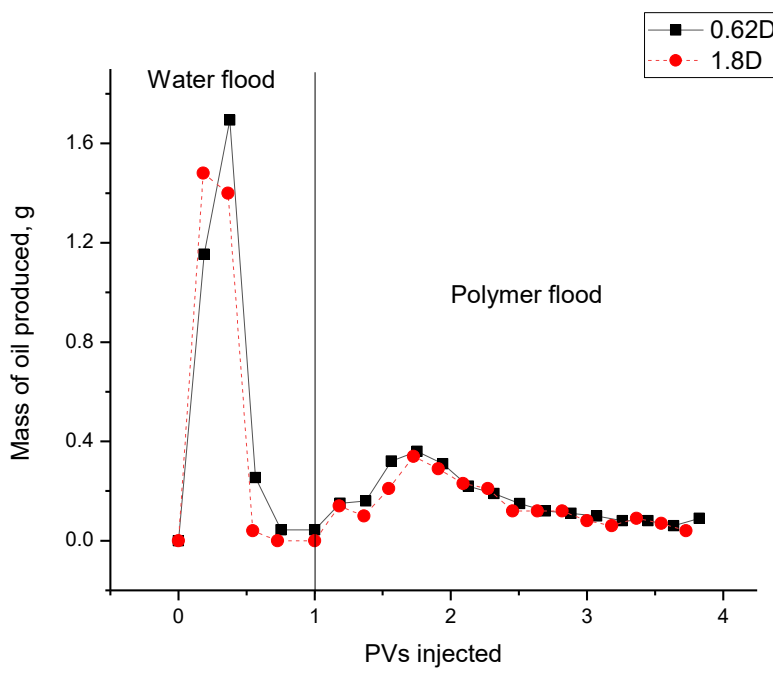

Figure 12 - Mass of oil produced during water flooding

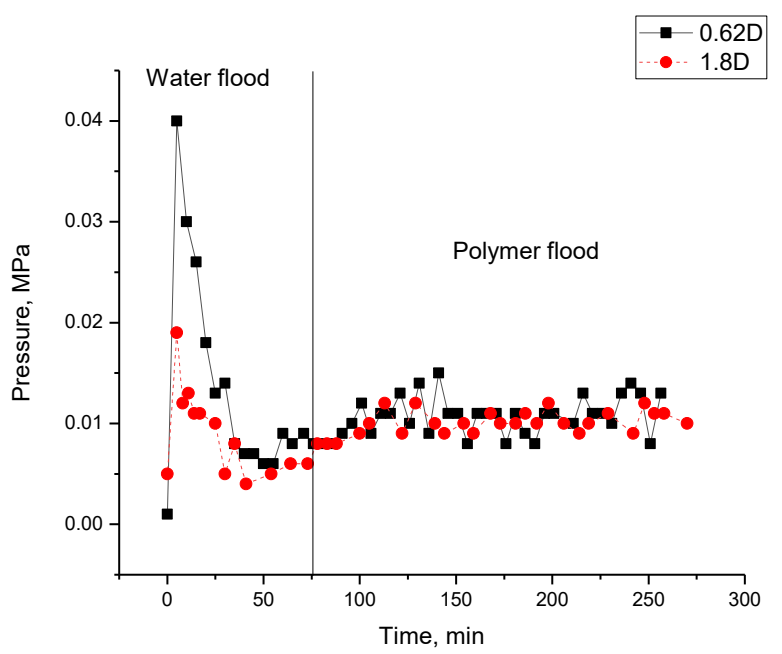

Figure 13 - Injection pressure versus time during the water flooding process 
The oil recovery factor (ORF) during water and polymer flooding is illustrated in Figure 14. In the case of water flooding, the ORF curves leveled off at around $36 \%$ and $30 \%$ for the 0.62 $\mathrm{D}$ and $1.8 \mathrm{D}$ models, respectively. The injection of $0.25 \mathrm{wt} . \%$ polyampholyte dissolved in $200 \mathrm{~g} \cdot \mathrm{L}^{-1}$ brine resulted in a rise of incremental oil recovery by 28 and $23 \%$ for the $0.62 \mathrm{D}$ and $1.8 \mathrm{D}$ sand pack models, respectively.

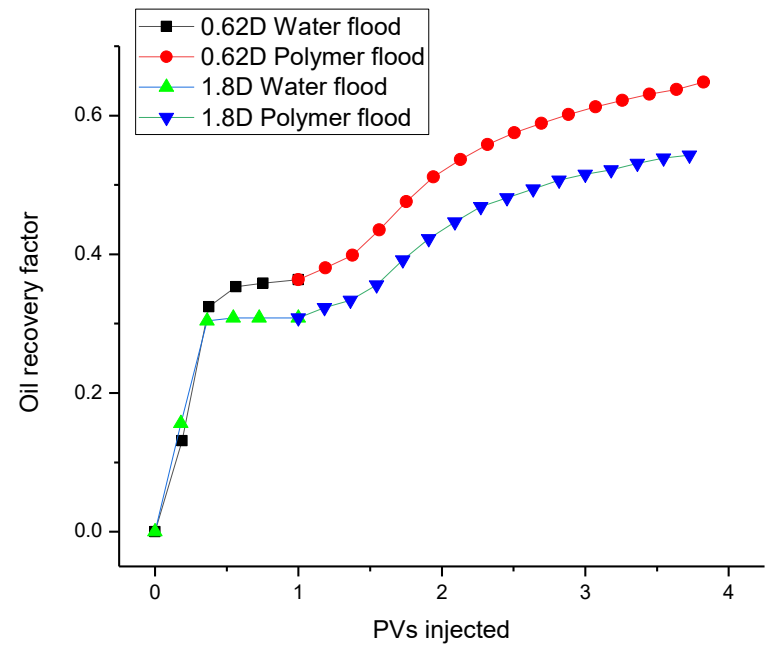

Figure 14 - Oil recovery factor for water and polymer flooding

\section{Conclusion}

High molecular weight amphoteric terpolymer based on acrylamide, 2-acrylamido-2-methyl-1-propanesulfonic acid sodium salt and (3-acrylamidopropyl) trimethylammonium chloride was synthesized and then characterized by various physico-chemical methods. The dynamic and reduced viscosities of AAm-AMPS-APTAC terpolymer were found to increase in saline water due to the antipolyelectrolyte effect. The dynamic viscosity of $0.25 \mathrm{wt} . \%$ amphoteric terpolymer solution increased from 7 to $14 \mathrm{mPa} \cdot \mathrm{s}$ upon a salinity increase from 200 to $300 \mathrm{~g} \cdot \mathrm{L}^{-1}$ at $24^{\circ} \mathrm{C}$. Injection of $0.25 \mathrm{wt} . \%$ amphoteric terpolymer solution prepared in $200 \mathrm{~g} \cdot \mathrm{L}^{-1}$ brine resulted in incremental oil recovery by 28 and $23 \%$ in 0.62 and $1.8 \mathrm{D}$ sand pack models, respectively. In future, the oil displacement ability of high molecular weight amphoteric terpolymer will be compared with high molecular weight hydrolyzed polyacrylamide, which is widely used in Kazakhstan as a polymer flooding agent.

\section{Acknowledgments}

This research was funded by the Science Committee of the Ministry of Education and Science of the Republic of Kazakhstan (Grant No. AP09260574). Authors thank Prof. Nurxat Nuraje from Nazarbayev University for provision of assistance in providing of SEM and TEM measurements. We thank Mr. Jack Combs (Kazakhstan) for careful editing and redacting of the manuscript.

\section{References (GOST)}

1 Pitts G.N., Paul B.C. Low areal sweep efficiencies in flooding heterogeneous rock. - Proceedings of SPE Production Techniques Symposium. - Wichita Falls, Texas, United States, 1970. - P.31.

2 Sydansk R.D., Romero-Zeron L. (2011) Reservoir conformance improvement. SPE, Richardson, United States.

3 Wang D., Hao Y., Delamaide E., Ye Zh., Ha S., Xiangcheng J. Results of two polymer flooding pilots in the central area of Daqing oil field // Proceedings of SPE Annual Technical Conference and Exhibition. - Houston, Texas, United States, 1993. - P.299.

4 Zhao Y., Yin Sh., Seright R.S., Ning S., Zhang Y., Bai B. Enhancing Heavy-Oil-Recovery Efficiency by Combining Low-SalinityWater and Polymer Flooding // SPE Journal. - 2021. - Vol.26. - P.1535-1551.

5 Abhijit S., Achinta B., Keka O., Ajay M. Effects of Alkali, Salts, and Surfactant on Rheological Behavior of Partially Hydrolyzed Polyacrylamide Solutions // Journal of Chemical Engineering. - 2010. - Vol.55(10). - P.4315-4322.

6 Bruno M.O., Silveira L.F., Rosângela B.Z. Rheological approach of HPAM solutions under harsh conditions for EOR applications // International Journal of Engineering and Technology. - 2016. - Vol.16, Is.03. - P.1-8.

7 Mungan N. Shear Viscosities of Ionic Polyacrylamide Solutions // SPE Journal. - 1972. - Vol.12. - Vol.469-473.

8 Moradi-Araghi A., Peter H.D. Hydrolysis and Precipitation of Polyacrylamides in Hard Brines at Elevated Temperatures // SPE Reservoir Engineering. - 1987. - Vol.2. - P.189-198.

9 Kudaibergenov S. Polyampholytes: synthesis, characterization and application. - Kluwer Academic/Plenum Publishers, United States, 2002.

10 Kudaibergenov S. Polyampholytes: past, present, perspectives. - Almaty, Kazakhstan, 2021.

11 Kudaibergenov S., Okay O. Behaviors of quenched polyampholytes in solution and gel state // Polymers for Advanced Technologies. - 2020. - Vol.32, Is.7. - P.2639-2654.

12 Mukhametgazy N., Gussenov I., Shakhvorostov A., Kudaibergenov S. Salt tolerant acrylamide-based quenched polyampholytes for polymer flooding // Bulletin of Karaganda University. Chemistry Series. - 2020. - Is.4(100). - P.119-127.

13 Fu X., Yang Q., Zhang Y. Thermal decomposition behavior and mechanism study of cationic polyacrylamide // Journal of Thermal Analysis and Calorimetry. - 2020. - Vol.146. - P.1371-1381. 


\section{References}

1 Pitts GN, Paul BC (1970) Low areal sweep efficiencies in flooding heterogeneous rock. Proceedings of SPE Production Techniques Symposium, Wichita Falls, Texas, United States. P.31.

2 Sydansk RD, Romero-Zeron L (2011) Reservoir conformance improvement. SPE, Richardson, United States. ISBN: 978-1-55563$302-8$

3 Wang D, Hao Y, Delamaide E, Ye Zh, Ha S, Xiangcheng J (1993) Results of two polymer flooding pilots in the central area of Daqing oil field. Proceedings of SPE Annual Technical Conference and Exhibition, Houston, Texas, United States. P.299.

4 Zhao Y, Yin Sh, Seright RS, Ning S, Zhang Y, Bai B (2021) SPE J 26:1535-1551. https://doi.org/10.2118/204220-PA

5 Abhijit S, Achinta B, Keka O, Ajay M (2010) Journal of Chemical Engineering 55(10):4315-4322. https://doi.org/10.1021/ je100458a

6 Bruno MO, Silveira LF, Rosângela BZ (2016) International Journal of Engineering and Technology 16(03):1-8.

7 Mungan N (1972) SPE J 12:469-473. https://doi.org/10.2118/3521-PA

8 Moradi-Araghi A, Peter HD (1987) SPE Reservoir Eng 2:189-198. https://doi.org/10.2118/13033-PA

9 Kudaibergenov S (2002) Polyampholytes: synthesis, characterization and application. Kluwer Academic/Plenum Publishers, United States. ISBN 978-1-4615-0627-0

10 Kudaibergenov S (2021) Polyampholytes: past, present, perspectives. Almaty, Kazakhstan.

11 Kudaibergenov S, Okay O (2020) Polym Advan Technol 32(7):2639-2654. https://doi.org/10.1002/pat.5112

12 Mukhametgazy N, Gussenov I, Shakhvorostov A, Kudaibergenov S (2020) Bulletin of Karaganda University. Chemistry Series 4(100):119-127. https://doi.org/10.31489/2020Ch4/119-127

13 Fu X, Yang Q, Zhang Y (2020) J Therm Anal Calorim 146:1371-1381. https://doi.org/10.1007/s10973-020-10131-0 